\title{
Can pulmonary vasodilators improve survival in cor pulmonale due to hypoxic chronic bronchitis and emphysema?
}

There has been a recent reawakening of interest in the effects of vasodilators in the pulmonary circulation, particularly in "blue bloaters"-that is, patients with chronic cor pulmonale as a complication of hypoxic chronic bronchitis and emphysema. Although we do not yet know whether lowering pulmonary arterial pressure in such patients improves survival, there is indirect evidence to suggest that it does. We know that survival of "blue bloaters" is related to the severity of their pulmonary hypertension, ${ }^{1.6}$ and it is apparent that continuous long term domiciliary oxygen therapy can improve survival in some of these hypoxaemic patients. ${ }^{78}$ This effect may be associated with an improvement in pulmonary haemodynamics. ${ }^{9.12}$ Thus oxygen may improve pulmonary haemodynamics and also prolong survival. Could further improvement in pulmonary haemodynamics with vasodilator drugs add to this effect?

\section{Mechanism of hypoxic pulmonary hypertension}

We first consider current understanding of the mechanisms underlying pulmonary hypertension in chronic bronchitis and emphysema, and the effect of long term oxygen on the pulmonary circulation, before discussing other drugs which may act as pulmonary vasodilators. Hypoxic pulmonary vasoconstriction of the small pulmonary arterioles, as seen at high altitude, is associated with muscularisation of these vessels, and contraction of this muscle is thought to be the primary mechanism of this form of hypoxic pulmonary hypertension. ${ }^{1314}$ If young men, however, native to a high altitude, where their arterial oxygen tension is about $6.5 \mathrm{kPa}(50 \mathrm{~mm} \mathrm{Hg})$ and their mean resting pulmonary arterial pressure about 24 $\mathrm{mm} \mathrm{Hg}$, go to live at sea level for two years, their mean pulmonary arterial pressure falls to normal values ( 12 $\mathrm{mm} \mathrm{Hg}$ ) and pulmonary vascular resistance halves. ${ }^{15}$ In chronic hypoxaemia due to chronic bronchitis and emphysema the muscularisation of small pulmonary

Address for reprint requests: Professor D C Flenley, Department of Respiratory Medicine, City Hospital, Edinburgh EH10 5SB. arterioles seen at high altitude is also accompanied by the development of longitudinal smooth muscle in the vessel intima. ${ }^{16}{ }^{17}$ Such scanty evidence as is available does not suggest that this longitudinal muscle disappears with partial correction of hypoxaemia by long term oxygen therapy. ${ }^{18}$

Patients with chronic airflow limitation due to chronic bronchitis and emphysema are often recognised as falling into two categories. Firstly, the "blue and bloated" characteristically have severe arterial hypoxaemia, and thus central cyanosis, along with carbon dioxide retention, pulmonary hypertension, and often secondary polycythaemia. Secondly, the "pink and puffing" will have only mild arterial hypoxaemia when at rest, but this is associated with a normal or low level of arterial carbon dioxide tension, normal pulmonary arterial pressures, and no secondary polycythaemia. Earlier notions that "blue bloaters" had principally bronchitis whereas "pink puffers" had mainly emphysema, although widespread in relatively recent textbooks, ${ }^{19}$ are probably untrue. Thus postmortem studies have shown that patients classified as "pink puffers" or "blue bloaters" in life had similar degrees of emphysema at necropsy. ${ }^{20}$ Recent studies using a new computed tomography method have shown that regional lung density in vivo correlates with enlargement of distal airspaces (the defining characteristic of emphysema) in lungs or lobes resected for peripheral tumours. ${ }^{21}$ In a further application of this method we have found that the extent of emphysema did not relate to mean pulmonary arterial pressure, either at rest or during exercise, in 32 patients with chronic bronchitis and emphysema with a wide range of airflow limitation and $F E V_{1}$ ranging from 0.35 to 3.92 litres. $^{22}$ It is important to emphasise that the "blue bloater" and "pink puffer" concepts describe clinical patterns and imply that pulmonary hypertension is related to hypoxaemia, and not necessarily to the extent of airflow limitation. This idea derives strong support from a large European cooperative study, ${ }^{23}$ which reported that in 595 patients with chronic bronchitis and emphysema the level of pulmonary arterial hypertension related most closely to resting arterial oxygen saturation $\left(\mathrm{SaO}_{2}\right)$ 
measured when patients were awake. Indeed, in that study $\mathrm{SaO}_{2}$ alone could explain $43 \%$ of the variance of pulmonary arterial pressure, whereas adding $F_{E V}$ in a multiple regression equation that included $\mathrm{SaO}_{2}$ explained only a further $1 \%$ of the variance. $\mathrm{FEV}_{\text {, }}$ alone was less well correlated with pulmonary arterial pressure than was $\mathrm{SaO}_{2}$. In fact, almost one tenth of these patients with severe airflow limitation $\left(\mathrm{FEV}_{1}<\right.$ 0.71 ) had a normal pulmonary arterial pressure at rest, as has been noted in one of the classic papers describing the two clinical patterns of this disease. ${ }^{24}$

In important studies of the clinical course of established pulmonary hypertension in these patients Weitzenblum et $a l^{25}$ found that the rate of rise in pulmonary arterial pressure varied widely between individual patients with chronic bronchitis and emphysema, and that this did not correlate with the slow fall in $\mathrm{SaO}_{2}$ that they documented over several years in their patients. ${ }^{25}$ Other factors may therefore contribute to pulmonary hypertension in this condition. Secondary polycythaemia may increase pulmonary vascular resistance, at least in theory; but actual measurements of pulmonary haemodynamics show only minor improvements when either venesection ${ }^{27}$ or erythrapheresis ${ }^{28}$ is used to lower the red cell mass acutely in these patients. The loss of up to one half of a normal pulmonary vascular bed, as occurs after pneumonectomy, has long been known to cause only a trivial rise in the resting mean pulmonary arterial pressure, ${ }^{29}$ suggesting that the destruction of the pulmonary vascular bed in emphysema is unlikely by itself to be a major factor in increasing the pulmonary vascular resistance, at least when the patient is at rest. ${ }^{17}$

The combination of evidence from studies of altitude hypoxia, along with the clinical, pathological, and therapeutic data reviewed above, thus strongly indicates the importance of hypoxia, which has a major causative role in chronic pulmonary hypertension in patients with chronic bronchitis and emphysema ("blue bloaters").

\section{Long term oxygen therapy}

Early uncontrolled studies of continuous domiciliary oxygen therapy suggested that the correction of hypoxaemia could reduce pulmonary arterial pressure. ${ }^{9-11}$ The two controlled trials of long term oxygen therapy, however, did not show a consistent fall in pulmonary arterial pressure with oxygen, ${ }^{78}$ despite improvements in survival. Acute correction of hypoxaemia in these patients is well known to cause only a slight fall in pulmonary arterial pressure and it does not restore it to normal. ${ }^{30}$ Nevertheless, long term oxygen therapy did appear to prevent a further rise in pulmonary arterial pressure in the Medical Research Council study, in contrast to the further rise seen in the control patients, who were treated without long term oxygen. ${ }^{7}$ In the National Institutes of Health study of long term oxygen treatment there was a fall in $\bar{c}$ pulmonary arterial pressure, at least in those treated with continuous oxygen therapy for 12 hours in the 24 hour day. ${ }^{6}$ Long term oxygen therapy given during the sleeping hours can prevent both the fall in $\mathrm{SaO}_{2}$ during rapid eye movement sleep in blue bloaters and the further rise in pulmonary arterial pressure during the hypoxaemic episodes. ${ }^{31}$

As survival in blue bloaters is related to their mean pulmonary arterial pressure, we may reasonably ask whether a reduction in pulmonary arterial pressure to a level below that which results from long term oxygen therapy can further improve their long term survival.

\section{Pulmonary vasodilatation}

Do any of the present potential pulmonary vasodilator agents show enough promise to justify the complex, long term, and inevitably costly study that is required to answer this question? Do we know the properties of an ideal pulmonary vasodilator agent? No agent, other than oxygen, has been convincingly shown to vasodilate the pulmonary circulation alone, without causing systemic vasodilatation, postural hypotension, or increase in cardiac output with the resulting possibility of a secondary rise in pulmonary arterial pressure. Reversal of hypoxic pulmonary vasoconstriction may also raise the blood flow to poorly ventilated alveoli with an increase in the shunt fraction, so that the arterial oxygen tension may actually fall. When this does occur the rise in cardiac output may still mean that the delivery of oxygen to the tissues is nevertheless increased.

How should we assess the results of vasodilator treatment? Debate continues on the best method of calculating pulmonary vascular resistance. Early evidence that the pressure-flow relationship in the pulmonary circulation was linear ${ }^{32-34}$ and passed through the origin has recently been questioned. ${ }^{35}{ }^{36}$ Treatment of hypoxic pulmonary vasoconstriction ideally requires modification of the vasoconstrictor response of the pulmonary blood vessels to hypoxia. Until the mechanism of this vasoconstrictor effect becomes known, ${ }^{37}$ there is little possibility of developing specific pharmacological antagonists to this action. The observation that the ventilatory stimulant almitrine may enhance the pulmonary vasoconstrictor response in these hypoxic patients, ${ }^{38}$ causing a modest rise in pulmonary arterial pressure during exercise at least ${ }^{39}$ may shed light on the mechanism of hypoxic pulmonary vasoconstriction. In most other respects pulmonary vascular smooth muscle responds in an identical fashion to systemic vascular smooth muscle, yet hypoxia tends to constrict the pulmonary circula- 
tion. As will be seen, however, all the current potential pulmonary vasodilator agents also dilate the systemic circulation to some degree.

\section{Pulmonary vasodilators}

Since the introduction of cardiac catheterisation the effects of over 20 agents have been assessed on the pulmonary circulation and the number is increasing rapidly. ${ }^{40}$ Many early studies were carried out in patients with pulmonary hypertension secondary to heart disease, whereas more recently studies have tended to concentrate on patients with primary pulmonary hypertension. The pathophysiological mechanisms causing pulmonary hypertension in these conditions may be very different from those in chronic bronchitis and emphysema. We will therefore review only the studies concerning patients with hypoxaemic chronic bronchitis and emphysema.

We still have no accurate non-invasive method of assessing pulmonary arterial pressure in man, particularly in patients with a hyperinflated chest as in chronic bronchitis and emphysema; assessment of potential pulmonary vasodilators demands right heart catheterisation. Thus few investigators have studied the long term haemodynamic effects of these drugs, despite the obvious relevance of such studies to their proposed therapeutic use. For the same reason, long term dose-response studies have not been carried out, most workers having used a single dose of drug in all the patients studied. The optimal dose of many potential pulmonary vasodilators in any given patient is therefore largely unknown, and this could explain some of the contradictions between different studies of the same agent, in addition to the obvious problem of comparing patients with different degrees of pathophysiological derangement.

We consider two types of drugs: the commonly used bronchodilators (theophyllines and $\beta_{2}$ agonists) and some of the more recent "vasodilators" -for example, hydralazine, captopril, the calcium antagonists, and $\alpha$ adrenergic blockers.

\section{THEOPHYLLINES}

Most studies of the effect of theophylline on the pulmonary circulation have not related observed effects to plasma theophylline concentrations. It is not certain whether the effects described occur only at concentrations that are therapeutic for bronchodilation. ${ }^{41}$ In acute studies theophylline has been repeatedly shown to reduce both mean pulmonary artery pressure and pulmonary vascular resistance in patients with chronic bronchitis and emphysema, but the effects on cardiac output have been variable. ${ }^{42-45}$ Arterial oxygen saturation may fall, despite any ventilatory stimulation from the theophylline. ${ }^{44}$ The right ventricular ejection fraction has been reported to rise after acute treatment with theophylline ${ }^{46}$ and this effect was sustained during three months of treatment. ${ }^{47}$

\section{BETA AGONISTS}

Both $\alpha$ and $\beta$ adrenergic receptors are present in the human pulmonary circulation, ${ }^{48}$ with evidence accumulating to suggest that there are vasoconstrictor $\alpha$ receptors and vasodilator $\beta$ receptors. ${ }^{32}{ }^{49}$ Selective $\beta_{2}$ agonists (salbutamol, terbutaline, and pirbuterol) cause a fall in pulmonary vascular resistance after either intravenous or oral administration ${ }^{50-56}$ and a rise in cardiac output. None the less, most studies have also shown a fall in mean pulmonary arterial pressure. The relative contributions of a direct cardiac inotropic effect and the vasodilator effect from $\beta_{2}$ agonists to explain the increase in cardiac output are unclear. In many studies $\mathrm{SaO}_{2}$ has also fallen. ${ }^{50} 525556$ In one study we found that one oral dose of pirbuterol lowered pulmonary arterial pressure, but this effect was not sustained over six months of oral treatment, suggesting that tachyphylaxis may develop in the pulmonary circulation during chronic treatment with $\beta_{2}$ adrenergic agonists. ${ }^{57}$ Thus $\beta_{2}$ agonists are unlikely to have a major role in the treatment of chronic hypoxic pulmonary hypertension.

\section{ALPHA ADRENERGIC BLOCKERS}

Non-selective $\alpha$ adrenergic antagonists (phentolamine, tolazoline) vasodilate the pulmonary circulation in patients with pulmonary disease. ${ }^{5859}$ Prazosin, a selective postsynaptic $\alpha$ antagonist, lowers pulmonary arterial pressure and increases cardiac output in patients with chronic bronchitis and emphysema after both one and eight weeks of treatment. ${ }^{60}$ There was, however, a fall in $\mathrm{SaO}_{2}$ associated with an increase in dyspnoea in these patients. ${ }^{60}$ Urapadil, another selective postsynaptic $\alpha$ antagonist, has been claimed to have a unique pharmacological action in reducing central sympathetic tone and inhibiting baroreceptor pressor responses. ${ }^{61}$ It is also claimed to have a selective action on the pulmonary circulation, a fall in pulmonary arterial pressure being associated with little change in cardiac output. ${ }^{61}$ These results, however, were described in a group of patients that included those with both obstructive and restrictive lung disease, in whom the mean pulmonary arterial pressure ranged widely from 3.3 to $8.5 \mathrm{~mm} \mathrm{Hg}$ $(25-64 \mathrm{kPa})$.

\section{HYDR A L A ZINE}

Agents that can relax vascular smooth muscle include diazoxide, and the calcium channel blockers. Hydralazine has mostly been used in primary pulmonary hypertension. ${ }^{62}$ In patients with hypoxaemic 
chronic bronchitis and emphysema it has been shown to reduce pulmonary vascular resistance, with a variable reduction in mean pulmonary arterial pressure. ${ }^{63-66}$ But such studies show considerable variability between patients in the extent of pulmonary vasodilatation with hydralazine treatment. In contrast to the results of earlier animal studies, ${ }^{67}$ arterial oxygen tension falls very little after hydralazine in man, suggesting that the drug does not inhibit hypoxic pulmonary vasoconstriction directly. Hydralazine predominantly produces systemic vasodilatation with a rise in cardiac output, and this can be associated with a rise in pulmonary arterial pressure. It has been suggested that possibly a quarter of hypoxaemic patients with chronic bronchitis and emphysema will not respond to hydralazine, either showing no fall or even a rise in pulmonary arterial pressure, secondary to the increase in cardiac output. ${ }^{68}$ The systemic lupus erythematosus syndrome has followed long term hydralazine treatment when this has been given in a dose of $200 \mathrm{mg}$ a day or more. ${ }^{69}$

\section{CALCIUM CHANNEL BLOCKERS}

Drugs that block slow calcium channel (calcium antagonists) do not form a homogeneous group and there are substantial differences in their pharmacological actions. ${ }^{70}$ The effects of the most widely used calcium antagonists (verapamil, diltiazem, and nifedipine) on the pulmonary circulation have all recently been studied in patients with hypoxaemic chronic bronchitis. In animal studies calcium channel blockers, in particular nifedipine, can prevent or even reverse hypoxic pulmonary vasoconstriction..$^{71-74}$ However, both diltiazem and verapamil have been shown to have no effect on pulmonary haemodynamic measurements in patients with chronic bronchitis and emphysema. ${ }^{7576}$

\section{NIFEDIPINE}

Nifedipine is a potent systemic vasodilator. There are several recent reports of the acute effect of $10-20 \mathrm{mg}$ of sublingual nifedipine. ${ }^{77-83}$ At rest nifedipine has reduced pulmonary vascular resistance and increased cardiac output in all but one study. ${ }^{81}$ Not all studies, however, have found a fall in pulmonary arterial pressure with nifedipine, though in two studies nifedipine significantly reduced pulmonary arterial pressure on exercise. ${ }^{783}$ Nifedipine nearly always causes a slight fall in $\mathrm{SaO}_{2}$ but in all studies the increase in cardiac output has actually improved the delivery of oxygen to the tissues. This raises the possibility that the exercise tolerance of these patients might be improved, if it is limited by delivery of oxygen to exercising muscles and not only by mechanical limitations to the ventilatory demands of the exercise. The matching of alveolar ventilation to perfusion may be further impaired by nifedipine, implying that the drug may partially reverse hypoxic pulmonary vasoconstriction. ${ }^{80}$ In two studies of the chronic effects of nifedipine the pulmonary vasodilator action has been shown to persist for 14 days, ${ }^{84}$ and after six to nine weeks of treatment. ${ }^{78}$ There was no symptomatic benefit, however, with this long term treatment and two patients deteriorated clinically despite persistent haemodynamic improvement. ${ }^{78} \mathrm{~A}$ similar study of felodipine, a calcium antagonist with a pharmacological action similar to that of nifedipine, found persistent haemodynamic benefit after 12-18 weeks of treatment $^{85}$ but little symptomatic improvement. Nitrendipine, another new calcium antagonist similar to nifedipine, has recently been shown to produce pulmonary vasodilatation for up to 10 months but again with no improvement in either symptoms or survival, according to this uncontrolled study ${ }^{86}$ In a one year placebo controlled study of the effects of nifedipine in patients with proved pulmonary hypertension secondary to hypoxaemic chronic bronchitis, Philip-Joet $e^{t} a^{\beta 7}$ found no clinical or symptomatic benefit, although the patients did not have a repeat catheterisation and it is therefore uncertain whether the haemodynamic responses persisted.

Nifedipine is thus a pulmonary vasodilator that may interfere with hypoxic pulmonary vasoconstriction. Should it therefore be combined with long term oxygen therapy? In their original study of nifedipine in patients with acute respiratory failure Simmoneau $e t$ $a l^{7}$ could find no additional benefit when nifedipine was added to oxygen therapy. An important detailed double blind controlled study, however, of four patients with stable bronchitis and one hypoxic patient with kyphoscoliosis (oxygen tension while they were breathing air at rest $6.0-7.9 \mathrm{kPa}(45-59 \mathrm{~mm} \mathrm{Hg})$ ) clearly showed a greater haemodynamic benefit when nifedipine was combined with oxygen, both at rest and during exercise. ${ }^{79}$

\section{ANGIOTENSIN CONVERTING ENZYME (ACE)} INHIBITORS

Finally, the angiotensin converting enzyme inhibitors may have a part to play in such patients. Although earlier studies suggested a central role for angiotensin II in hypoxic pulmonary vasoconstriction, this has not been confirmed. ${ }^{88-90}$ Controversy persists about the role of the renin-angiotensin system in hypoxaemic cor pulmonale, and of angiotensin converting enzyme in vascular responses to hypoxia. ${ }^{9192}$ The angiotensin converting enzyme inhibitor enalapril has recently been shown convincingly to improve both symptoms and survival in patients with congestive heart failure but with no respiratory disease..$^{93}$ In severely hypoxaemic patients with chronic bronchitis and emphysema Burke et $a l^{4}$ found that $25 \mathrm{mg}$ captopril 
given three times daily significantly reduced pulmonary arterial pressure and pulmonary vascular resistance. This was associated with a rise in cardiac output but no significant fall in $\mathrm{SaO}_{2}$, so that again tissue oxygen delivery was increased. In contrast, a further study of captopril ${ }^{95}$ in patients with hypoxic cor pulmonale found no change in pulmonary haemodynamic measurements, nor did a similar study of enalapril ${ }^{96}$ in a similar group of patients. Clearly, further studies are required to resolve this conflict, and to see whether improvement in survival similar to that achieved in patients with congestive heart failure without respiratory disease $e^{93}$ can be obtained in cor pulmonale due to chronic hypoxaemic bronchitis and emphysema.

\section{Conclusion}

Pulmonary vasodilators are generating much interest. So far the only treatment shown by controlled clinical trials to prolong life in hypoxaemic chronic bronchitis and emphysema is long term oxygen. This treatment may delay progression of pulmonary hypertension in these "blue and bloated" patients. No other medication has yet been convincingly shown to do either. The two groups of drugs currently showing most promise as pulmonary vasodilators, the nifedipine like calcium antagonists and the angiotensin converting enzyme inhibitors, may directly interfere with the pulmonary vasoconstrictor response to hypoxia; but again the evidence for such an action is conflicting. Nevertheless, both types of drugs appear to merit further study, but this will need small scale placebo controlled studies of longer term treatment, with pulmonary haemodynamic monitoring, to determine whether the pulmonary vasodilator response persists (for it did not with $\beta_{2}$ agonists). If such studies show persistent pulmonary vasodilatation, then and only then will large scale studies of the effects of pulmonary arterial vasodilators on symptoms (including exercise tolerance) and survival be justified-but these studies would seem to require long term oxygen therapy in both treatment and placebo regimens. Since there is as yet no convincing scientific evidence that any pulmonary vasodilator improves either prognosis or symptoms in patients with hypoxaemic chronic bronchitis and emphysema, these drugs have at present no established place in the treatment of such patients.

KF WHYTE DC FLENLEY

Rayne Laboratory

University Department of Respiratory Medicine City Hospital, Edinburgh EHIO 5SB

\section{References}

1 Renzetti AD Jr, McClement JH, Litt BD. Veterans
Administrative cooperative study of pulmonary function. III: Mortality in relation to respiratory function in chronic obstructive pulmonary disease. $\mathrm{Am} \mathrm{J} \mathrm{Med}$ 1966;41:115-29.

2 Sadoul P, Schrijen F, Uffholtz H, Pham QT. Evolution clinique de 195 pulmonaires soumis a un catheterisme du coeur droit entre 1957 et 1965. Bull Physiopathol Respir 1968;4:225-40.

3 Weitzenblum E, Hirth C, Ducolone A, Mirhom R, Rasaholinjanahary J, Ehrhart M. Prognostic value of pulmonary artery pressure in chronic obstructive pulmonary disease. Thorax 1981;36:752-8.

4 WHO Multicentre Study. Physiological variables and mortality in patients with various categories of chronic respiratory disease. Bull Eur Physiopathol Respir 1984;20:495-500.

5 Keller R, Ragaz A, Borer P. Predictors for early mortality in patients with long-term oxygen home therapy. Respiration 1985;48:216-21.

6 Timms RM, Khaja FU, Williams GW, and the Nocturnal Oxygen Therapy Trial Group. Haemodynamic response to oxygen therapy in chronic obstructive pulmonary disease. Ann Intern Med 1985;102:29-36.

7 Medical Research Council Working Party. Long term domiciliary oxygen therapy in chronic hypoxic cor pulmonale complicating chronic bronchitis and emphysema. Lancet 1981;i:681-6.

8 Nocturnal Oxygen Therapy Trial Group. Continuous or nocturnal oxygen therapy in hypoxaemic chronic obstructive lung disease. Ann Intern Med 1980;93:391-8.

9 Levine BE, Bigelow DB, Hamstra RD, Beckwitt HJ, Mitchell RS, Neff LM, Stephen TA, Petty TL. The role of long-term continuous oxygen administration in patients with chronic airways obstruction with hypoxemia. Ann Int Med 1967;66:639-50.

10 Abraham AS, Cole RB, Bishop JM. Reversal of pulmonary hypertension by prolonged oxygen administration to patients with chronic bronchitis. Circ Res 1968;23:147-57.

11 Stark RD, Finnegan P, Bishop JM. Long-term domiciliary oxygen in chronic bronchitis with pulmonary hypertension. $\mathrm{Br}$ Med $J$ 1973;3:467-70.

12 Weitzenblum E, Sautegeau A, Ehrhart M, Mammosser $M$, Pelletier A. Long-term oxygen therapy can reverse the progression of pulmonary hypertension in patients with chronic obstructive pulmonary disease. Am Rev Respir Dis 1985;131:493-8.

13 Arias-Stella J, Saldana M. The terminal portion of the pulmonary arterial tree in people native to high altitudes. Circulation 1963;28:915-25.

14 Heath D, Williams DR. Man at high altitude. 2nd ed. Edinburgh: Churchill Livingstone, 1981:268.

15 Sime F, Penaloza D, Ruiz L. Bradycardia, increased cardiac output and reversal of pulmonary hypertension in altitude natives living at sea level. Br Heart $J$ 1971;33:647-57.

16 Haselton PS, Heath D, Brewer DB. Hypertensive pulmonary vascular disease in states of chronic hypoxia. $J$ Pathol Bact 1968;95:431-40.

17 Harris P, Heath D. The human pulmonary circulation. 3rd ed. New York: Churchill Livingstone, 1986:512-21.

18 Wilkinson M, Langhorne CA, Heath D, Barer GR, 
Howard P. Pathology and pathophysiology of the pulmonary circulation after long term domiciliary oxygen therapy [Abstract]. Thorax 1986;41:716.

19 McFadden ER, Braunwald E. Cor pulmonale and pulmonary thromboembolism. In: Braunwald E, ed. Heart disease. A textbook of cardiovascular medicine. 2nd ed. Philadelphia: WB Saunders, 1984:1572-604.

20 Mitchell RS, Stanford RE, Silvers GW, Dart G. The right ventricle in chronic airway obstruction: a clinicopathologic study. Am Rev Respir Dis 1976;114:147-54.

21 Gould GA, MacNee W, McLean A, et al. Measurements of lung density in life can quantitate distal air space enlargement-an essential defining feature of human emphysema. Am Rev Respir Dis (in press).

22 Biernacki W, Whyte KF, Gould GA, Belloni A, Flenley DC. The extent of pulmonary emphysema as assessed non-invasively by CT scan in life does not relate to pulmonary haemodynamics during rest or exercise [Abstract]. Thorax 1986;41:726.

23 Bishop JM, Cross KW. Use of other physiological variables to predict pulmonary arterial pressure in patients with chronic respiratory disease: Multicentre study. Eur Heart J 1981;2:509-17.

24 Filley GF, Beckwitt HJ, Reeves JT, Mitchell RS. Chronic obstructive bronchopulmonary disease. II Oxygen transport in two clinical types. Am J Med 1968;44:2638 .

25 Weitzenblum E, Sautegeau A, Ehrhart M, Mammoser M, Hirth C, Roegel E. Long term course of pulmonary arterial pressure in chronic obstructive pulmonary disease. Am Rev Respir Dis 1984;130:993-8.

26 Weitzenblum E, Jezek V. Evolution of pulmonary hypertension in chronic respiratory diseases. Bull Eur Physiopathol Respir 1984;20:73-81.

27 Segel N, Bishop JM. The circulation in patients with chronic bronchitis and emphysema at rest and during exercise with special reference to the influence of changes in blood viscosity and blood volume on the pulmonary circulation. $J$ Clin Invest $1966 ; 45: 1555-68$.

28 Wallis PJW, Skehan JD, Newland AC, Wedzicha JA, Mills PG, Empey DW. Effects of erythrapheresis on pulmonary haemodynamics and oxygen transport in patients with secondary polycythaemia and cor pulmonale. Clin Sci 1986;70:91-8.

29 Cournand A, Riley RL, Himelstein A, Austrian R. Pulmonary circulation and alveolar ventilation perfusion relationships after pneumomectomy. $J$ Thorac Surg 1950;19:80-116.

30 Cotes JE, Pisa Z, Thomas AJ. Effect of breathing oxygen upon cardiac output, heart rate, ventilation, systemic and pulmonary blood pressure in patients with chronic lung disease. Clin Sci 1963;25:305-21.

31 Fletcher EC, Levin DC. Cardiopulmonary haemodynamics during sleep in subjects with chronic obstructive pulmonary disease. The effect of short and long term oxygen. Chest 1984;85:6-14.

32 Harris P, Segel N, Bishop JM. The relationship between pressure and flow in the pulmonary circulation in normal subjects and patients with chronic bronchitis and mitral stenosis. Cardiovasc Res 1968;2:73-83.

33 Widimsky J. Pressure flow and volume changes in the lesser circulation during pulmonary artery occlusion in healthy subjects and patients with pulmonary hypertension. Prog Respir Res 1970;5:224-36.

34 Even P, Duroux P, Ruff F, Caubarrere I, de Vernejoul P, Brouet $\mathrm{G}$. The pressure flow relationship of the pulmonary circulation in normal man and in chronic obstructive pulmonary diseases. Effects of muscular exercise. Scand J Respir Dis 1971;suppl 77:72-6.

35 Versprille A. Pulmonary vascular resistance: a meaningless variable. Intens Care Med 1984;10:51-3.

36 McGregor M, Sniderman A. On pulmonary vascular resistance: the need for more precise definition. Am J Cardiol 1985;55:217-21.

37 Voelkel NF. Mechanisms of hypoxic pulmonary vasoconstriction. Am Rev Respir Dis 1986;133:118695.

38 Romaldini H, Rodriguez-Roisin P, Wagner PD, West JB Enhancement of hypoxic pulmonary vasoconstriction by almitrine in the dog. Am Rev Respir Dis 1983;128:288-93.

39 MacNee W, Connaughton JJ, Rhind GB, et al. A comparison of the effects of almitrine or oxygen breathing on pulmonary arterial pressure and right ventricular ejection fraction in hypoxic chronic bronchitis and emphysema. Am Rev Respir Dis 1986;134:559-65.

40 Harris $\mathrm{P}$, Heath D. The human pulmonary circulation. 3rd ed. New York: Churchill Livingstone, 1986:185-205.

41 Rall TW. Central nervous system stimulants: the methylxanthines. In: Goodman-Gilman A, Goodman LS, Rall TW, Murad F, eds. Goodman and Gilman's The pharmacological basis of therapeutics. 7th ed. New York: MacMillan Publishing Co, 1985:589-603.

42 Parker JO, Ashekian PB, Di Giorgi S, West RO. Haemodynamic effects of aminophylline in chronic obstructive pulmonary disease. Circulation 1967;35:365-72.

43 Parker JO, Kelkar K, West RO. Haemodynamic effects of aminophylline in cor pulmonale. Circulation 1966;33:17-25.

44 Jezek V, Ourednik A, Stepanek J, Boudik F. The effect of aminophylline on the respiration and pulmonary circulation. Clin Sci 1970;38:549-54.

45 Stein PA, Leu JD, Welch MH, Guenter CA. Pathophysiology of pulmonary circulation in emphysema associated with alpha-1 antitrypsin deficiency. Circulation 1971;43:227-39.

46 Matthay RA, Berger HJ, Loke L, Gottschalk A, Zaret BL. Effects of aminophylline upon right and left ventricular performance in chronic obstructive pulmonary disease. Am J Med 1978;65:903-10.

47 Matthay RA, Berger HJ, Davies R, Loke J, Gottschalk $A$, Zaret BL. Improvement in cardiac performance by oral long-acting theophylline in chronic obstructive pulmonary disease. Am Heart $J$ 1982;104:1022-6.

48 McLean JR. Pulmonary vascular innervation. In: Bergofsky EH, ed. Abnormal pulmonary circulation. 3rd ed. New York: Churchill Livingstone, 1986:27-53.

49 Bergofsky EH. Vasodilators in chronic obstructive pulmonary disease. In: Bergofsky EH, ed. Abnormal pulmonary circulation. 3rd ed. New York: Churchill Livingstone, 1986:313.

50 Koziorowski A, Zielinski J, Maszczyk Z, Pawlicka L, 
Klimkiewicz H. Effect of salbutamol on pulmonary circulation, ventilation and gas exchange in patients with chronic obstructive airways disease. Preliminary report. Bull Physiopathol Respir 1972;8:611-6.

51 Stockley RA, Finnegan P, Bishop JM. Effect of intravenous terbutaline on arterial blood gas tensions, ventilation and pulmonary circulation in patients with chronic bronchitis and cor pulmonale. Thorax 1977;32:601-5.

52 Teule GJJ, Majid PA. Haemodynamic effects of terbutaline in chronic obstructive airways disease. Thorax 1980;35:536-42.

53 Jones RM, Stockley RA, Bishop JM. Early effects of intravenous terbutaline on cardiopulmonary function in chronic obstructive bronchitis and pulmonary hypertension. Thorax 1982;37:746-50.

54 Brent BN, Mahler D, Berger HJ, Matthay RA, Pytlik L, Zaret BL. Augmentation of right ventricular performance in chronic obstructive pulmonary disease by terbutaline; a combined radionuclide and haemodynamic study. Am J Cardiol 1982;50:313-9.

55 MacNee W, Wathen CG, Hannan WJ, Flenley DC, Muir AL. Effects of pirbuterol and sodium nitroprusside on pulmonary haemodynamics in hypoxic cor pulmonale. Br Med J 1983;287:1169-72.

56 Peacock A, Busst C, Dawkins K, Denison DM. Response of pulmonary circulation to oral pirbuterol in chronic airflow obstruction. $\mathrm{Br} \mathrm{Med} J$ 1983;287:1178-80.

57 Biernacki WB, Whyte KF, Prince K, MacNee W, Flenley DC. Does the addition of an oral beta-2 agonist (pirbuterol) to long term oxygen therapy yield further benefit in hypoxic chronic bronchitis and emphysema? [Abstract]. Clin Sci 1987;72suppl 16:54-5P.

58 Gould L, Zahir M, De Martino A, Gomprecht RF. Haemodynamic effects of phentolamine in chronic obstructive pulmonary disease. $\mathrm{Br}$ Heart $\mathrm{J}$ 1971;33:445-50.

59 Widimsky J, Kasalicky J, Valach A, Dejdar R, Vyslouzil A, Lukes M. Effect of priscol on the pulmonary circulation in cor pulmonale. Br Heart $J$ 1960;22:5718.

60 Vik-Mo H, Walde N, Jentoft H, Halvorsen FJ. Improved haemodynamics but reduced arterial blood oxygenation, at rest and during exercise after long-term oral prazosin therapy in chronic cor pulmonale. Eur Heart $J$ 1985;6:1047-53.

61 Adnot S, Defouilloy C, Brun-Buisson C, Abrouk F, Piquet J, Lemaire F. Haemodynamic effects of urapidil in patients with pulmonary hypertension. A comparative study with hydralazine. Am Rev Respir Dis 1987;135:288-93.

62 Rubin LJ, Peter RH. Oral hydralazine therapy for primary pulmonary hypertension. $N$ Engl J Med 1980;302:69-73.

63 Keller CA, Shepard JW, Chun DS, Dolan GF, Vasquez $P$, Minh VD. Effects of hydralazine on haemodynamics, ventilation and gas exchange in patients with chronic obstructive pulmonary disease and pulmonary hypertension. Am Rev Respir Dis 1984;130:606-11.

64 Rubin LJ, Peter RH. Haemodynamics at rest and during exercise after oral hydralazine in patients with cor pulmonale. Am J Cardiol 1981;47:116-22.
65 Miller MJ, Chappell TR, Cook W, De Olazabal JR, Rubin LJ. Effects of oral hydralazine on gas exchange in patients with cor pulmonale. Am J Med 1983;75:937-42.

66 Nogare ARD, Rubin LJ. The effects of hydralazine on exercise capacity in pulmonary hypertension secondary to chronic obstructive lung disease. Am Rev Respir Dis 1986;133:385-9.

67 Rubin LJ, Lazar JD. Influence of prostaglandin synthesis inhibitors on pulmonary vasodilatory effects of hydralazine in dogs with hypoxic pulmonary vasoconstriction. J Clin Invest 1981;67:193-200.

68 Peter RH, Rubin LJ. The pharmacologic control of the pulmonary circulation in pulmonary hypertension. Adv Intern Med 1986;29:507-9.

69 Rudd P, Blaschke TF. Antihypertensive agents and the drug therapy of hypertension. In: Goodman-Gilman A, Goodman LS, Rall TW, Murad F, eds. Goodman and Gilman's The pharmacological basis of therapeutics. 7th edition. New York: Macmillan Publishing Co, 1985:795-6.

70 Opie LH. Calcium antagonists. Mechanisms, therapeutic indications and reservations: a review. $Q \mathrm{~J} \mathrm{Med}$ 1984;53:1-16.

71 McMurty IF, Davidson AB, Reeves JT, Grover R. Inhibition of hypoxic pulmonary vasoconstriction by calcium antagonists in isolated rat lungs. Circ Res 1976;38:99-104.

72 Kennedy T, Summer W. Inhibition of hypoxic pulmonary vasoconstruction by nifedipine. Am J Cardiol 1982;50:864-8.

73 Young TE, Lundquist LJ, Chelser E, Weir EK. Comparative effects of nifedipine, verapamil, and diltiazem on experimental pulmonary hypertension. Am J Cardiol 1983;51:195-200.

74 Stanbrook HS, Morris KG, McMurty IF. Prevention and reversal of hypoxic pulmonary hypertension by calcium antagonists. Am Rev Respir Dis 1984;130:81-5.

75 Clozel JP, Delorme N, Battistella P, Breda JL, Polu JM. Haemodynamic effects of intravenous diltiazem in hypoxic pulmonary hypertension. Chest 1987;91:1715.

76 Brown SE, Linden GS, King RR, Blair GP, Stansbury DW, Light RW. Effects of verapamil on pulmonary haemodynamics during hypoxaemia, at rest, and during exercise in patients with chronic obstructive pulmonary disease. Thorax 1983;38:840-4.

77 Simmoneau G, Escourrou P, Duroux P, Lockhart A. Inhibition of hypoxic pulmonary vasoconstriction by nifedipine. N Engl J Med 1981;304:1582-5.

78 Sturani C, Bassein L, Schiavina M, Gunella G. Oral nifedipine in chronic cor pulmonale secondary to severe chronic obstructive pulmonary disease. Short and long term haemodynamic effects. Chest 1983;84:135-42.

79 Kennedy TP, Michael JR, Huang CK, Kallman $\mathrm{CH}$, Zahka K, Schlott W, Summer W. Nifedipine inhibits hypoxic pulmonary vasoconstriction during rest and exercise in patients with chronic obstructive pulmonary disease. Am Rev Respir Dis 1984;129:544-51.

80 Melot C, Halleman R, Naieje R, Mols P, Lejeune P. Deleterious effect of nifedipine on pulmonary gas 
exchange in chronic obstructive pulmonary disease. Am Rev Respir Dis 1984;130:612-6.

81 Gaucher LR, Payen DM, Minsart PJ, Peltier PM, Ordronneau JJ, Grolleau JY. Effects of nifedipine on pulmonary arterial hypertension in patients with respiratory insufficiency without acute failure. Respiration 1984;45:443-9.

82 Muramoto A, Caldwell J, Albert RK, Lakshirminarayan $\mathbf{S}$, Butler J. Nifedipine dilates the pulmonary vasculature without producing symptomatic systemic hypotension in upright resting and exercising patients with pulmonary hypertension secondary to chronic obstructive pulmonary disease. Am Rev Respir Dis 1985;132:963-6.

83 Singh H, Ebejer MJ, Higgins DA, Henderson AH, Campbell IA. Acute haemodynamic effects of nifedipine at rest and during maximal exercise in patients with chronic cor pulmonale. Thorax 1985;40:910-4.

84 Saadjian A, Philip-Joet F, Guintoli A, Torresani J, Arnaud A. Two weeks nifedipine therapy for pulmonary hypertension complicating chronic obstructive lung disease. Eur J Respir Dis 1985;67:346-50.

85 Bratel T, Hedenstierna G, Nyquist O, Ripe E. Long term treatment with a new calcium antagonist, felodipine, in chronic obstructive lung disease. Eur $J$ Respir Dis 1986;68:351-61.

86 Rubin LJ, Moser K. Long term effects of nitrendipine on haemodynamics and oxygen transport in patients with cor pulmonale. Chest 1986;89:141-5.

87 Philip-Joet F, Saadjian A, Vestri R, Austran P, Arnaud A. One year follow-up study of nifedipine in the treatment of secondary pulmonary hypertension [Abstract]. Eur J Respir Dis 1986;69(suppl 146):A128.
88 Berkhov S. Hypoxic pulmonary vasoconstriction in the rat. The necessary role of angiotensin II. Circ Res 1974;35:256-61.

89 Zakheim RM, Mattioli L, Molteni A, Mullis KB, Bartley J. Prevention of pulmonary vascular changes of chronic alveolar hypoxia by inhibition of angiotensinI-converting enzyme in the rat. Lab Invest 1975;33:5761.

90 Prewitt RL, Leffler CW. Feline hypoxic pulmonary vasoconstriction is not blocked by the angiotensin-I converting enzyme inhibitor, captopril. $J$ Cardiovasc Pharmacol 1981;3:293-8.

91 Studdy PR, Lapworth R, Bird R. Angiotensin-converting enzyme and its clinical significance-a review. $J$ Clin Pathol 1983;36:938-47.

92 Milledge JS. Angiotensin converting enzyme and hypoxia. Bull Eur Physiopathol Respir 1984;20:481-5.

93 The CONCENSUS trial study group. Effects of enalapril on mortality in severe congestive heart failure: results of the cooperative North Scandinavian enalapril survival study (CONCENSUS). $N$ Engl $J$ Med 1987;316:1429-35.

94 Burke CM, Harte M, Duncan J, Connolly HM, Morgan JH, Theodore J, Callaghan B. Captopril and domiciliary oxygen in chronic airflow obstruction. $\mathrm{Br}$ Med J 1985;290:1251.

95 Zielsinski J, Hawrylkiewicz I, Goreika D, Gluskowski J, Koslinska M. Captopril effects on pulmonary and systemic haemodynamics in chronic cor pulmonale. Chest 1986;90:562-5.

96 Neilly JB, Carter R, Morton JT, Stevenson RD. Acute haemodynamic, hormonal and gas exchange effects of enalapril (MK 422) in stable cor pulmonale [Abstract]. Am Rev Respir Dis 1987;135:A515. 